УДК 327-049.5(477.5/.7:1-662Нато+4СС)

DOI 10.30970/vir.2019.47.0.10982

\title{
THE CONCEPT OF RESILIENCE IN THE EUROPEAN NEIGHBOURHOOD POLICY
}

\author{
Marianna Gladysh \\ Ivan Franko National University of Lviv, \\ 1, Universytetska Str., Lviv, Ukraine, 79000, tel. (032) 2394132, \\ e-mail:mgladysh@ukr.net
}

The conceptual foundations of term resilience in modern political science are highlighted, in particular the meaning of the concept of «resilience» in modern international relations, the key conceptual approaches used in research to understand resilience, which characterizes the response of subjects to stress, threat of any kind and origin, but its generally accepted definition has not yet been formed. The application of this concept in the documents of the European Union, in particular in the «EU Global Strategy for Foreign and Security Policy» in 2016, is studied. Particular attention is paid to policies towards third countries, with a special focus on sustainability policies towards them. The stages of formation of the European Neighbourhood Policy are traced. The problems and prospects of the EU cooperation with the Mediterranean countries and the Eastern Partnership countries are highlighted, namely the format and mechanisms of its existence; existing and potential obstacles. The main achievements and challenges of the Eastern Partnership policy implementation at the present stage are studied. The main achievements of Ukraine on the way of realization of its European integration policy, in particular achievements within the framework of the Eastern Partnership are defined.

Key words: resilience; EU; European Neighbourhood Policy; Eastern Partnership; Ukraine.

Introduction. The concept of «resilience» took an important place in the European Neighbourhood Policy (ENP) in 2015, a year before it was brought to the level of a key concept in the EU Global Strategy on Foreign and Security Policy (GSFSP). The processes in the neighbouring regions of the European Union have become one of the key factors for emerging the termin resilience in its external activity.

The regions of partnerships were in the focus of the main strategic document already in 2003. During that period, Brussels declared the level of safety of the European Union in terms of external factors. In 2004 the official launch of the ENP took place, designed to allow the formation of such borders along the perimeter of the $\mathrm{EU}$, so that they would not become new dividing lines for closer cooperation with

(C) Gladysh Marianna, 2019 
neighbouring states. At the same time, the ENP should also have to become a tool for transforming the states according to the guidelines set by Brussels. The goal was to assist in the formation of more secure and open for cooperation neighbouring regions both in the south and in the east.

The following years demonstrated the interconnection between the security of a united Europe and the situation in neighbouring states and regions. At the same time, the ENP and other unilateral initiatives of Brussels could not prevent the emergence of hotbeds of instability along the perimeter of the EU.

Resilience in the EU discourse. The concept of resilience has gradually come to all policies of the EU and foreign and security policy is not an exception. The evolution of the term has gone through several strages. For the first time the term «resilience» entered the academic discourse in 1973 in the paper 'Resilience and stability of ecological systems' by C. S. Holling [17]. Gradually it has reached other academic spheres such as psychology, economics, social sciences. Though, political science has not exploited this term for many years and only at the end of the XXthbeginning of the XXI century it has come into the discourse of political leaders and international organizations.

The first mention of the term «resilience» in the documents of the EEC (the predecessor of the EU) dates back to the 1980s. The word was mainly used in the field of economic regulation. In particular, the European Commission and the Council of Ministers (later the Council of the EU, hereinafter referred to as the Council) spoke about resilience during the period of fluctuations in oil prices, crises in the banking sector, economic recession and inflation [32]. At the same time, the EEC began to emphasize the importance of ecosystem resilience in the context of unsustainable use of natural resources. In the 1990s, there are references to the resilience of databases in the European Union, but the main sphere of the use of this term was economics and environmental protection.

At the beginning of the XXI century, the term «resilience» is gradually penetrating into other social spheres, mainly to foreign and security policy. In the late 1990s, the EU began also to use the term in relations with third countries - at first mainly concerning environmental resilience of developing countries and the need to improve it. 2005 was a turning point in the practice of using the term in the European Union, when the issue of resilience of state institutions and civil society in third countries in the face of various dangers was raised. The EU's special responsibility for the resilience of small developing countries was also noted [26].

Political components are gradually filling the content of the category of «resilience». However, the normativeness of resilience is not high. «The European Consensus on Development Policy», which the EU adopted in 2006, first emphasizes on the vulnerability to natural disasters, environmental problems and external economic shocks that developing countries should be helped with, and only then mentions a long-term vision EU - to promote the building of legitimate, effective and resilient public institutions and a vibrant, organized civil society [26].

On 28 June 2016, the High Representative for Foreign Affairs and Security Policy and Vice President of the European Commission (HR/VP), Federica Mogherini, 
officially presented the «EU Global Strategy for Foreign and Security Policy» (hereafter EUGS) to the European Council. Resilience is defined in the EUGS as «the ability of states and societies to reform, thus withstanding and recovering from internal and external crises» (EUGS 2016, p. 23) [13]. More specifically, building «state and societal resilience to our East and South» is identified as one of the five key priorities for the EU's external action.

Resilience in the ENP. When the European Neighbourhood Policy (hereinafter ENP) was launched in 2004, the European Union was more optimistic about the situation in neighbouring countries than in 2015, when the use of the «resilience» was sharply expanded. However, the objectives of the ENP and its features until 2015 did not fundamentally differ from those that appear after the penetration of resilience into this policy.

At the very beginning of the ENP, the formula «Everything, except institutions» was put forward for new neighbours [29]. Its essence was, that the European Union was not ready to consider the issues of membership, but offered maximum rapprochement in the field of economy, trade, security for those states that share common values with the EU and were moving along the path of the reforms indicated by it. The issue of reforming remained, as before, a key element of the EU's interaction with its neighbours. The Neighbourhood Policy, or Wider Europe, was planned to become a region of prosperity and cooperation under the auspices of the EU, thereby contributing to its own security [8].

The ENP had to solve several interrelated tasks. Firstly, to structure the space surrounding the EU, separating, for example, countries with prospects of membership in the medium term from other groups of neighbours; to create the toolkit applied to different categories of neighbouring states. Secondly, to link the internal consolidation of the European Union with its external dimension.

The evolution of the ENP up to 2015 perfectly showed the problems which resilience could theoretically lessen. They are significant differences between neighbouring countries; the problem of balance between the EU's interaction with states and with the civil societies of its neighbours.

One of the characteristic features of the ENP concerns the major differences not only between the eastern and southern neighbouring states, but also among the states of each of the regions. This has been noted from the very beginning of the ENP. In particular, the existence of significant differences between the EU's neighbouring states was enshrined in the principle of differentiation in the first Communique of the Neighborhood Policy of the European Commission [11]. It was based not only on internal differences and peculiarities of regions and states, but on their different progress in relations with the EU. For example, it was indicated that eastern neighbouring states, unlike the southern ones, still did not have preferential trade agreements with the EU.

Differences among neighbouring states were established depending on the dynamics and content of their relations with the European Union. In accordance with this logic, Belarus and Libya were excluded from full participation in the 
neighborhood policy already at its start. Brussels tried in this way to demonstrate its serious attitude towards issues of democracy and human rights.

Gradually the ENP evolved towards a greater separation of the two dimensions. One of the reasons was the different interests of the member-states of the European Union in two directions: for the states of Western and Southern Europe, the southern vector was the priority, for the countries of Central, Eastern and Northern Europe - the eastern one.

The key innovations of the Union for the Mediterranean region, created in 2008 [21], were joint participation of the EU member-states and partners in cooperation, co-chairmanship, holding summits every two years and generally increasing of the level of cooperation, work on specific projects. The Union should have emphasized the features of the southern neighborhood, and take into account the needs of individual states and communities in the south. At the same time, the multilateral dimension of cooperation was preserved. Nevertheless, the project had several problems, which did not allow better taking into account the specifics of the south. First, the Union included 43 very heterogeneous states: in addition to all EU member states and ENP partners (Libya is an observer), these are Monaco, countries with a prospect of EU membership (Albania, Bosnia and Herzegovina, Montenegro, Turkey) and Mauritania, relations with which the EU is building within the framework of development policy. The hydrocarbon exporter Algeria also saw limited benefits for itself. Indicative was the sharp criticism of Libyan leader Muammar Gaddafi, whose pan-African, pan-Arab and pan-Islamic geopolitical aspirations came into conflict with the Union for the Mediterranean [33].

Comparing to the previous format of partnership, the Union's concentration on projects in narrow areas derived it from the problems of democracy and human rights [6, p. 370]. This, on the one hand, indicated another rollback of the EU from promoting its norms. On the other hand, this separated the Union from the requests in the region.

In the east, the Eastern Partnership (EaP) was launched in 2009. Since the process of its transformation from the Swedish-Polish initiative into the official part of the European Neighborhood Policy coincided with the Russian-Georgian war in 2008, the competitive component prevailed in the concept of the EaP. The institutionalization of the Eastern dimension of the ENP took place in a situation where a significant part of the EU representatives were clearly striving to isolate themselves from Russia by a buffer zone of states oriented towards rapprochement.

The innovation of the EaP was the introduction of a multilateral dimension. The idea was to stimulate such multilateral cooperation between the Eastern partners, which would orient them towards rapprochement with the EU. The institutions such as EaP summits, ministerial meetings, four thematic platforms, the Civil Society Forum, the Inter-Parliamentary Assembly, the Business Forum and the Youth Forum were formed. As in the south, conflicts between individual countries (for example, between Armenia and Azerbaijan) have become a significant obstacle to the implementation of the multilateral dimension [7]. 
Processes in the neighboring countries themselves had a fundamental impact on the adjustment of the EU's approaches. For example, public protests led to a change in political regimes in a number of states. The first wave fell on the eastern border of the EU (Georgia in 2003, Ukraine in 2004, Moldova in 2009). These events were perceived in the EU as an indicator that the peoples of neighboring states are sometimes more than the ruling elites disposed to implement the European model in their countries. This was followed by the events of the so-called «Arab Spring» in the south mergins of the European Union. In connection with the fall of authoritarian regimes in North Africa, and programs to support civil society and promote human rights were strengthened (for example, the European Instrument for Democracy and Human Rights) [30].

Thus, by the time of the infiltration of the resilience concept into the EU foreign policy discourse, the European Neighborhood Policy, despite regular attempts at reforms, could not get rid of the key contradictions since its emergence and arising from its very essence. The ENP continued to be asymmetrical and one-sided. Moreover, in the process of evolution, it acquired some new features.

In 2015, the President of the European Commission Jean-Claude Juncker initiated another reform of the ENP, formulating a number of questions for public consultations [20].

The development of the EU Global Strategy on Foreign and Security Policy was Brussels' response to numerous challenges. A special impact had the events in the southern and eastern neighborhood mainly an escalation of civil confrontation and a humanitarian crisis. The fall of the authoritarian regimes also gave way to chaos, and the region began to export to Europe those problems and threats that had previously been controlled with varying degrees of success (illegal migration, terrorism, etc.). In the east, the aggressive policy of Russian Federation has led to a a crisis in international agreements, especially in the field of security.

The European Union's Global Strategy was supposed to provide answers to the question of how Brussels is going to overcome multiple challenges. A separate section is devoted to neighbouring regions, which indicates that investing in strengthening of the state and social resilience of the neighbouring countries are in the interests of the EU citizens, since a resilient neighbour is safe and does not export threats to the European Union. Moreover, resilience is defined in the Strategy as the ability of states and societies to carry out reforms, and their goal is to build a democratic state characterized by citizens' trust in political institutions, effective and responsible governance, as well as sustainable development. Resilience is contrasted with fragility. According to the authors of the document, «repressive» states are fragile in the long term, while democracies are resilient [13].

The EU Global Strategy on Foreign and Security Policy and the 2015 Communication developed the idea, first expressed in 2006, that many of the challenges the EU is facing and its close neighbours cannot be adequately addressed without the involvement of the so-called «neighbours of neighbours» [27].

For the Eastern neighbourhood these are the states of Central Asia, for the Southern one - the space from the Persian Gulf to Central Africa. In this regard, the 
GSFSP separately mentions the systems of regional cooperation, which the authors of the strategy also call co-operative regional orders. Thus, in the south, the Middle East, Mediterranean region and Africa are named as the space for the formation of such potential orders. In the east, we are talking about a possible pairing EaP with projects in Central Asia.

Resilient EaP. With the end of the bloc confrontation, the eastern border of the EEC, and then the European Union, turned out to be more movable than the southern one. The space of European civilization was never limited to Western Europe, and the states of Central and Eastern Europe perceived the collapse of the socialist system as a chance to return to Europe.

The EU enlargments in 2004 and 2007 seriously moved the borders of the European Union to the east, covering even part of the former Soviet republics (the Baltic states). Some other states in the region (Ukraine, Moldova), which declared the European choice, expected that they would become the next candidates for membership. However, the European Union was not ready to consider even distant prospects of their membership, and the European post-Soviet countries, together with their southern neighbours, were included in the EaP.

The core of the EU's neighbourhood policy for Armenia, Azerbaijan, Belarus, Georgia, Moldova, and Ukraine is the offer for these countries to use financial and technical assistance from the EU to overhaul their post Soviet economies and democratise political systems. In return, they would get visa-free travel, customs-free trade, and greater political cooperation with the EU. The trouble with this approach was that the prospects for success largely depend on the willingness of the region's political elites to push for this kind of change [24].

Being in the same group with its southern neighbours caused dissatisfaction among the leadership of some eastern neighbours, for example Ukraine. Nevertheless, the increasingly noticeable pressure from Russia, as well as the attractiveness of certain elements of the EU for various groups of the population contributed to the preservation and even strengthening of the European vector of the foreign policy of these states.

The Russian factor had a significant impact on the dynamics of the development of the Eastern dimension of the ENP. Moreover, at the present stage, the aggressive policy of Russian Federation in the region have become one of the factors in introducing the concept of resilience into the foreign policy discourse of the European Union, including the EaP.

Particular differences between the various partner countries are seen through the prism of their associations with the EU. Thus, in 2012-2013, the European Union completed negotiations on concluding Association Agreements (AAs) with four Eastern countries: Armenia, Georgia, Moldova and Ukraine. The decision taken by Armenia in September 2013 to join the Custom Union made its AA with the EU irrelevant. Dramatic history of AA with Ukraine was after President Yanukovych's refusal to sign it at the Vilnius Eastern Summit on November 28-29, 2013 (including the Revolution of Dignity, Russia's opposition, and the Referendum in the Nertherlands), finally expired on September 1, 2017, when the AA with Ukraine 
entered into force. Earlier, on July 1, 2016, Association Agreements with Moldova and Georgia were launched, which brought these three countries into a separate institutional group of the East $[12 ; 5]$.

Thus, the conclusion and entry into force of Association Agreements with the three countries of the region was a key moment in the evolution of the Eastern Partnership and a factor that increased the differentiation between the partner countries. As a result, a separate format of the EU's relations with a group of associated countries, based on the implementation of the AA, has been launched within the framework of the EaP.

Its essential feature is the strengthening the rule of the EU law. The implementation of legal norms into the legal systems of Georgia, Moldova and Ukraine, especially in the areas covered by free trade areas, where the AAs provide for a clear commitment of the associated countries to gradually approximate their own legislation to the EU norms and standards. Within the AA, the European Union seeks to disseminate its values, principles and legal norms, defining them as conditions that must be met by associated countries in accordance with their contractual obligations.

Characterizing the achievements of the associated countries it is worth mentioning that currently the most significant result of the implementation of AAs has been the intensification of their trade with the EU. Even in the face of Russian military aggression and economic pressure, exports from Georgia, Moldova and Ukraine to the EU have grown significantly in recent years. Mutual trade has now become a real success story of Ukraine in the framework of the Eastern Partnership [16]. According to various experts, leaving GOST standards inherited from the Soviet Union, and the adoption of modern EU standards, adaptation of legislation to the acquis of the European Union and removal of non-tariff barriers contributed to the economic growth of the associated countries and created long-term prospects for their modernization and sustainable development. Three countries of the Eastern Partnership not only get wider access to the 500 million EU market, but also integrated into the global production and sales chains .

Within this framework, there is a joint commitment to deliver tangible results for citizens across the region. In support of a more results-oriented approach towards the Eastern Partnership, the European Commission and European External Action Service identified 20 key deliverables for 2020 [25], with milestones identified during the last EaP Summit, which took place in Brussels in November 2017.

These commitments by the EU, its Member States and the six Partner countries cover the four main priority areas of the Eastern Partnership:

Stronger Economy (economic development and market opportunities);

Stronger Governance (strengthening institutions and good governance);

Stronger Connectivity (connectivity, energy efficiency, environment and climate change);

Stronger Society (mobility and people-to-people contacts) [25].

On 18 March, 2020 Joint Communication on the EaP policy beyond 2020 «Reinforcing Resilience - an Eastern Partnership that delivers for all» was adopted. It is a new set of long-term policy objectives divided into 4 clusters. This document 
outlines the new long-term policy objectives for the Eastern Partnership beyond 2020 and sets out the measures that aim to strengthen resilience, foster sustainable development and deliver tangible results for society [18].

Building on the Partnership's key achievements, and recognising that strengthening resilience is an overriding policy framework, as outlined in the Strategic Approach to Resilience in the EU's external action, the EU, its Member States and the partner countries will work together on the following long-term Eastern Partnership policy objectives beyond 2020:

- $\quad$ together for resilient, sustainable and integrated economies;

- $\quad$ together for accountable institutions, the rule of law and security;

- $\quad$ together towards environmental and climate resilience;

- $\quad$ together for a resilient digital transformation; and

- $\quad$ together for resilient, fair and inclusive societies.

On 18 June, 2020 leaders from the EU and the six 'eastern partner' countries Armenia, Azerbaijan, Georgia, Moldova, Ukraine and Belarus met to mark the launch of the next phase of the EU's Eastern Partnership policy, which sets out the EU's approach to its eastern neighbourhood. It is an opportunity to ensure that the policy builds upon successes and is refreshed to reflect new geopolitical realities. Regrettably, the approach set out so far fails to deliver.

For Ukraine the Eastern Partnership is both hope and disappointment - since it does not respond to Ukraine's aspirations for the EU membership.

Though, me may define 10 achievements of the Eastern Partnership in terms of priorities and interests of Ukraine.

1) Intensified cooperation between Eastern European countries under the auspices of the European Union without the participation of Russia. Owing to the creation of the Eastern Partnership, the post-Soviet space has been reformatted, and the European Union's attention to the region has significantly increased. At the same time, Russia has lost its monopoly over some post-Soviet countries, including Ukraine. The Eastern Partnership countries have had the opportunity to strengthen political dialogue with the EU and with each other, to participate in the formation of a common agenda through participation in Eastern Partnership summits, meetings of Eastern Partnership ministers and other formats of political involvement. Thus, there is another platform for meetings with the leaders of the EU member states at the highest level, in contrast to bilateral summits, where only the leaders of the EU institutions are present.

2) Signing by Ukraine, Georgia and Moldova of Association Agreements with the EU and growth of trade with the European Union. Georgia and Moldova signed the Association Agreements in 2014, the same year these Agreements entered into force. In the case of Ukraine, this process took longer, due to the referendum in the Netherlands on the ratification of the Association Agreement, as well as the tripartite negotiations with Russia on the Deep and Comprehensive Free Trade Area. The Association Agreement between Ukraine and the EU was provisionally launched in 2014, except for the DCFTA, which became provisionally applicable in 2016, and the full Agreement entered into force on September 1, 2017. This is an ambitious 
document that has launched long-awaited reforms. The free trade zone opened to us by the Association Agreement promotes the growth of exports.

3) Implementation of the EU standards. In addition to the Association Agreement, the European Union offers partner countries other roadmaps for reforms. One of these is «20 achievements of the Eastern Partnership by 2020» [25]. Unlike the Association Agreement, the «20 achievements» are not binding, but cover some areas that are not in the Agreement, or clarify and supplement the Agreement. According to a study by experts of the Ukrainian National Platform of the Eastern Partnership Civil Society Forum, conducted in 2018, Ukraine has actively moved towards 17 of 20 achievements - in the areas of anti-corruption, public administration reform, security, small and medium business development, implementation of the Free Trade Area with the EU, environmental protection, visa liberalization, etc.

4) Visa-free regime with the European Union. The EU visa-free regime with Georgia and Moldova entered into force on March 28, 2017, and with Ukraine on June 11, 2017. As of May 2019, more than 2.5 million Ukrainians have already used visafree travel $[4 ; 5 ; 16]$.

5) Access to the EU programs. Through participation in the Eastern Partnership, Partner countries have the opportunity to participate in a number of programs operating under the European Neighborhood Policy or directly under the Eastern Partnership initiative. They are aimed at the development of small and medium-sized businesses, education, culture, science and innovation, academic mobility, urban infrastructure and more. These programs include initiatives such as EU4Business, EU4Energy, EU4Youth, Creative Europe, Culture and Creativity, Measures for Economic Growth, Covenant of Mayors - Demonstration Projects, Erasmus+, Horizon 2020, and Integrated Governance. Borders and others.

6) Raising awareness of the EU and its activities in Ukraine. Thanks to the development of cooperation between the European Union and the Eastern Partnership countries, the awareness of the citizens of these countries about the European Union and its activities has increased. This, in turn, helps to build confidence in the European Union. According to opinion polls, in 2018, $66 \%$ of Ukrainians trusted the EU - this is $7 \%$ more than in 2017 [1].

7) Feelings and awareness of Ukrainians belonging to the single European space. Deepening cooperation and integration with the European Union has strengthened Ukrainians' sense of being European. If in May $201334.3 \%$ of Ukrainians considered themselves Europeans, in October 2017 - $40 \%$, then in August 2018 - $44 \%$ of citizens [2].

8) Establishment of Eastern Partnership institutions for intergovernmental, interparliamentary and business cooperation. EU and Eastern Partnership government and experts work together within the East's Platforms and Thematic Panels. In addition, EU and Eastern Partnership foreign ministers usually meet once a year. Cooperation between the parliaments of the Eastern Partnership countries takes place within the framework of the EU Parliamentary Assembly - Eastern Neighbours (EURONEST PA). Belarus does not currently participate in EURONEST meetings for political reasons related to democracy in the country. In addition, in June 2018, the 
Ukraine-Moldova-Georgia Interparliamentary Assembly was established. Such platforms are helping to unite efforts to reform and deepen the integration of the six $\mathrm{EaP}$ countries with the EU, as well as to work on a vision for the further development of the Eastern Partnership.

9) Establishment of the Eastern Partnership Civil Society Forum for interaction between the Eastern Partnership public and strengthening their influence on national governments and EU institutions. The creation of the Forum provided a unique opportunity to network civil society organizations in the region and maintain dialogue with senior officials from 6 countries in the East and the EU. By joining forces, it is easier for the public to reach out to participating countries if it is necessary to draw attention to certain issues or put pressure on national governments.

10) Support by the European Union for stronger involvement of non-governmental organizations and citizens of partner countries in the implementation of the Eastern Partnership policy. In addition to the Civil Society Forum, there are a number of other instruments for the European Union to support the Eastern Partnership civil society organizations. With the launch of the Eastern Partnership, EU funding for such cooperation has increased. Special programs for training and skills development of civil society organizations have been launched.

\section{Conclusion.}

The concept of resilience has gradually come to all policies of the EU and foreign and security policy is not an exception. The first mention of the term "resilience" in the documents of the EEC (the predecessor of the EU) dates back to the 1980s. The word was mainly used in the field of economic regulation. At the beginning of the XXI century, the term «resilience» is gradually penetrating into other social spheres, mainly to foreign and security policy. In the late 1990s, the EU began also to use the term in relations with third countries. On 28 June 2016, the High Representative for Foreign Affairs and Security Policy and Vice President of the European Commission, Federica Mogherini, officially presented the «EU Global Strategy for Foreign and Security Policy» to the European Council. Resilience is defined in the EUGS as «the ability of states and societies to reform, thus withstanding and recovering from internal and external crises» (EUGS 2016, p. 23). More specifically, building «state and societal resilience to our East and South» is identified as one of the five key priorities for the EU's external action.

When the European Neighbourhood Policy was launched in 2004 it had to solve several interrelated tasks. Firstly, to structure the space surrounding the EU, separating, for example, countries with prospects of membership in the medium term from other groups of neighbours; to create the toolkit applied to different categories of neighbouring states. Secondly, to link the internal consolidation of the European Union with its external dimension. Gradually the ENP evolved towards a greater separation of the two dimensions. One of the reasons was the different interests of the member-states of the European Union in two directions: for the states of Western and Southern Europe, the southern vector was the priority, for the countries of Central, Eastern and Northern Europe - the eastern one. In the east, the Eastern Partnership (EaP) was launched in 2009. The innovation of the EaP was the introduction of a 
multilateral dimension. The idea was to stimulate such multilateral cooperation between the Eastern partners, which would orient them towards rapprochement with the EU. The eastern neighbourhood is at the frontline of competition between Russia and the West. Georgia, Moldova, and Ukraine all receive military assistance from the EU or NATO while facing Russian military presence within their recognised borders.

For Ukraine the Eastern Partnership is both hope and disappointment - since it does not respond to Ukraine's aspirations for the EU membership. Though, me may define 10 achievements of the Eastern Partnership in terms of priorities and interests of Ukraine: 1) Intensified cooperation between Eastern European countries under the auspices of the European Union without the participation of Russia; 2) Signing by Ukraine, Georgia and Moldova of Association Agreements with the EU and growth of trade with the European Union; 3) Implementation of the EU standards; 4) Visa-free regime with the European Union; 5) Access to the EU programs; 6) Raising awareness of the EU and its activities in Ukraine; 7) Feelings and awareness of Ukrainians belonging to the single European space; 8) Establishment of Eastern Partnership institutions for intergovernmental, interparliamentary and business cooperation; 9) Establishment of the Eastern Partnership Civil Society Forum for interaction between the Eastern Partnership public and strengthening their influence on national governments and EU institutions; 10) Support by the European Union for stronger involvement of non-governmental organizations and citizens of partner countries in the implementation of the Eastern Partnership policy.

\section{REFERENCES}

1. $63 \%$ українців довіряють Європейському Союзу [Електронний ресурс]. - Режим доступу : https://www.prostir.ua/?news=63-ukrajintsiv-doviryaje-evropejskomu-soyuzu.

2. Вважають себе європейцями 44\% українців [Електронний ресурс]. - Режим доступу : https://www.ukrinform.ua/rubric-society/2547846-vvazaut-sebe-evropejcami-44-ukrainciv.html.

3. Action Document for EU4Digital: Improving Cyber Resilience in the Eastern Partnership Countries [Electronic resource]. - Access mode : https://ec.europa.eu/neighbourhood-enlargement/sites/ near/files/c_2018_8184_f1_annex_en_v1_p1_1000418.pdf.

4. Association agenda between the European Union and Georgia 2017-2020 // EEAS [Electronic resource]. - Access mode : https://eeas.europa.eu/sites/eeas/files/annex_ii_-_eu-georgia_association_ agenda_text.pdf.

5. Association Agenda between the European Union and the Republic of Moldova, 2017-2019 // Official Journal of the European Union. 2017. August, 19 [Electronic resource]. - Access mode : https://eur-lex.europa.eu/legal-content/GA/TXT/?uri=CELEX:22017D1489.

6. Catalano S. L., Graziano P. R. Europeanization as a Democratization Tool? The Case of Morocco // Mediterranean Politics. 2016. Vol. 21, no. 3. P. 364-386 [Electronic resource]. - Access mode : https:// doi.org/10.1080/13629395.2015.1129778 - P. 370.

7. Communication from the Commission to the European Parliament and the Council. Eastern Partnership. [Electronic resource]. - Access mode : https://eur-lex.europa.eu/legal-content/EN/TXT/ $\mathrm{PDF} /$ ?uri=CELEX:52008DC0823\& from=EN.

8. Communication from the European Commission to the Council and the European Parliament. Wider Europe - Neighbourhood: A new framework for relations with our eastern and southern neighbours. [Electronic resource]. - Access mode : http://eeas.europa.eu/archives/docs/enp/pdf/pdf/ com03_104_en.pdf.

9. Eastern Partnership Index 2017. Eastern Partnership Civil Society Forum, December 2018 [Electronic resource]. - Access mode : https://eap-csf.eu/wp-content/uploads/EaP-Index-2017.pdf. 
10. Eastern Partnership Multilateral Platforms. General Guidelines and Rules of Procedure [Electronic resource]. - Access mode : http://eeas.europa.eu/archives/docs/eastern/platforms/rules_ procedure_en.pdf.

11. European Neighbourhood Policy in 2012: Continuing engagement for a stronger cooperation with neighbours despite turbulent political and economic conditions [Electronic resource]. - Access mode : https://ec.europa.eu/commission/presscorner/detail/en/IP_13_245.

12. European Parliament resolution of 27 February 2014 on the situation in Ukraine [Electronic resource]. - Access mode : https://www.europarl.europa.eu/sides/getDoc.do?pubRef=-//EP// NONSGML+TA+P7-TA-2014-0170+0+DOC+PDF+V0//EN.

13. European Union Global Strategy (EUGS), 2016. Shared vision, common action: A stronger Europe. A Global Strategy for the European Union's Foreign and Security Policy, June 2016 [Electronic resource]. - Access mode : http://europa.eu/globalstrategy/en/global-strategy-foreign-and-security-policyeuropean-union.

14. EU-Tunisia Action Plan, 2005 [Electronic resource]. - Access mode : https://library.euneighbours.eu/sites/default/files/attachments/tunisia_enp_ap_final_en.pdf.

15. EU-Ukraine Action Plan, 2005. [Electronic resource]. - Access mode https://library.euneighbours.eu/sites/default/files/attachments/ukraine_enp_ap_final_en_0.pdf.

16. EU-Ukraine Association Agenda to prepare and facilitate the implementation of the Association Agreement As endorsed by the EU-Ukraine Association Council on 16 March 2015 [Electronic resource]. - Access mode : //EEAS.https://eeas.europa.eu/archives/docs/ukraine/docs/ st06978_15_en.pdf.

17. Holling C. S. Resilience and Stability of Ecological Systems. Annual Review of Ecology and Systematics, 1973ю Vol. 4:1-23 (Volume publication date November 1973) [Electronic resource]. Access mode : https://doi.org/10.1146/annurev.es.04.110173.000245.

18. Joint Communication to the European Parliament and the Council. A Strategic Approach to Resilience in the EU's external action [Electronic resource]. - Access mode : https://eeas.europa.eu/sites/ eeas/files/join_2017_21_f1_communication_from_commission_to_inst_en_v7_p1_916039.pdf.

19. Joint Communication to the European Parliament, the Council, the European Economic and Social Committee and the Committee of the Regions. Review of the European Neighbourhood Policy. [Electronic resource]. - Access mode : http://eeas.europa.eu/archives/docs/enp/documents/2015/ 151118joint-communication_review-of-the-enp_en.pdf.

20. Joint Consultation Paper. Towards a new European Neighbourhood Policy [Electronic resource]. - Access mode : https://ec.europa.eu/neighbourhood-enlargement/sites/near/files/ neighbourhood/consultation/consultation.pdf.

21. Joint Declaration of the Paris Summit for the Mediterranean [Electronic resource]. - Access mode : https://ec.europa.eu/research/iscp/pdf/policy/paris_declaration.pdf.

22. Joint press statement following the 5th Association Council meeting between the EU and Ukraine // Council of the EU. 2018. December, 17 [Electronic resource]. - Access mode : https://www.consilium.europa.eu/en/press/press-releases/2018/12/17/joint-press-statement-following-the5th-association-council-meeting-between-the-european-union-and-ukraine/.

23. Joint press statement following the 5th Association Council meeting between the EU and Georgia // Council of the EU. 2019. March, 5 [Electronic resource]. - Access mode https://www.consilium.europa.eu/en/press/press-releases/2019/03/05/joint-press-statement-following-the5th-association-council-meeting-between-the-eu-and-georgia/.

24. Joint Staff Working Document. Eastern Partnership - Focusing on key priorities and deliverables [Electronic resource]. - Access mode : http://www.3dcftas.eu/system/tdf/near-eeas_joint_ swd_2016467_0.pdf?file $=1 \&$ type $=$ node $\&$ id $=271 \&$ force $=$.

25. Joint Staff Working Document. Eastern Partnership — 20 Deliverables for 2020. Focusing on key priorities and tangible results [Electronic resource]. - Access mode : https://library.euneighbours.eu/ sites/default/files/attachments/swd_2017_300_f1_joint_staff_working_paper_en_v5_p1_940530.pdf.

26. Joint statement by the Council and the representatives of the governments of the Member States meeting within the Council, the European Parliament and the Commission on European Union Development Policy: The European Consensus on Development [Electronic resource]. - Access mode : https://eur-lex.europa.eu/legal-content/EN/TXT/PDF/?uri=CELEX:42006X0224(01)\&from=EN. 
27. Lannon E. Extending the Geographical Scope of the ENP? The Neighbours of the EU's Neighbours // Euromed Survey of Experts and Actors. 6th ed. Barcelona, 2016. - P. 26-32.

28. Prichard A., 2013. Justice and EU foreign policy. Journal of contemporary European studies, 21 (3), 413-429.

29. Prodi R. A Wider Europe - A Proximity Policy as the Key to Stability. Brussels, 2002. [Electronic resource]. - Access mode : http://europa.eu/rapid/press-release_SPEECH-02-619_en.pdf.

30. Regulation (EU) No 236/2014 of the European Parliament and of the Council of 11 March 2014 laying down common rules and procedures for the implementation of the Union's instruments for financing external action.

31. n // Official Journal of the European Union. 2014. March, 15. L 77/95-108.Shared Vision, Common Action: A Stronger Europe. A Global Strategy for the European Union's Foreign and Security Policy [Electronic resource]. - Access mode : http://eeas.europa.eu/archives/docs/topstories/pdf/ eugs_review_web.pdf.

32. The Economic Situation in the Community. Communication from the Commission to the Council (Economic and Financial Affairs) for its meeting on Monday 17th March 1980. COM (80) 100 final Brussels, 5 March 1980. http://aei.pitt.edu/31706/1/COM_(80)100_final.pdf; Resolution on the Sixth United Nations Conference on trade and Development (UNCTAD). Belgrade, 6 June -1 July 1983 [Electronic resource]. - Access mode : https://publications.europa.eu/en/publication-detail//publication/e1192463-96d2-49ef-86e4-3be0332cb893/language-en.

33. Troudi M. F. L'Union pour la Méditerranée : le rêve et la réalité // Académie de Géopolitique de Paris. 29 Mars 2016 [Electronic resource]. - Access mode: http://www.academiedegeopolitiquedeparis.com/lunion-pour-la-mediterranee-le-reve-et-la-realite/.

34. Wagner, W. and Anholt, R., 2016. Resilience as the EU global strategy's new leitmotif: pragmatic, problematic, or promising? Contemporary security policy, 1-17.

Стаття надійшла до редколегії 10.06.2019

Прийнята до друку 01.09.2019

\title{
КОНЦЕПЦІЯ ОПІРНОСТІ В ЄВРОПЕЙСЬКІЙ ПОЛІТИЦІ СУСІДСТВА
}

\author{
Маріанна Гладиш \\ Львівський начіональний університет імені Івана Франка, \\ вул. Університетська, 1, м. Львів, Украӥна, 79000, тел. (032) 2394-132, \\ e-mail:mgladysh@ukr.net
}

Висвітлено концептуальні основи стійкості в сучасній політичній науці, зокрема зміст поняття «стійкість»» в сучасних міжнародних відносинах, проаналізовано ключові концептуальні підходи, які використовуються у наукових дослідженнях щодо розуміння стійкості, що характеризує реакцію суб'єктів на стрес, загрозу будь-якого роду і походження, однак загальноприйнятого iĭ визначення поки не сформовано. Досліджується застосування даного поняття в документах Європейського Союзу, зокрема в «Глобальній Стратегії ЄС щодо зовнішньої та безпекової політики» 2016 року. Особлива увага приділяється політиці стосовно третіх країн з особливим акцентом на політиці стійкості щодо них. Простежено етапи становлення Європейської політики сусідства. Висвітлено проблеми та перспективи співпраці ЄС з країнами Середземноморя та країнами «Східного партнерства», а саме формат і механізми його існування; наявні та потенційні перешкоди. Досліджено основні здобутки та виклики реалізації політики Східного партнерства на сучасному етапі. Визначено основні досягнення України на шляху реалізації ії євроінтеграційної політики, зокрема здобутки в рамках Східного партнерства.

Ключові слова: концепт стійкості; ЄС; Свропейська політика сусідства; Східне партнерство; Україна. 